\title{
Diversity in the board of directors and good governance practices
}

\author{
Álvaro Melón-Izco* • Francisco J. Ruiz-Cabestre • M. Carmen Ruiz-Olalla \\ Departamento de Economía y Empresa, Universidad de La Rioja, Spain
}

Received: 15 September 2019

Revised: 9 January 2020

Accepted: 30 January 2020

\begin{abstract}
Boards of directors must commit to balancing the interests of the stakeholders and not focusing exclusively on financial concerns. Motivated by the importance that diversity currently has in companies, we examine the effect that board diversity has on corporate governance performance in Spain, analysing gender diversity, diversity of director types and tenure diversity. The findings reveal that diverse boards of directors have a positive influence on good governance practices, improving the efficiency of corporate governance mechanisms. These results may have implications for practitioners, since it is shown that different types of diversity contribute to better corporate governance. They may also be of interest to regulators, who are rightly promoting laws and regulations aimed at achieving diversity in the knowledge, experiences, and gender of the board of directors.
\end{abstract}

Keywords: corporate governance; corporate governance performance; board of directors; board diversity; gender diversity

JEL Classification Codes: G3, G38, M14, M48

\section{Introduction}

Through literature we know that diversity in the board of directors translates into: (1) the reduction of agency costs (agency theory); (2) the optimization of the resource dependence function (resource dependence theory); (3) the improvement of corporate reputation by being more open to a multiplicity of interests (stakeholder theory). This theoretical basis is present in many of the researches they have studied the relationship between board diversity and financial performance and has done so by analysing diversity in a single dimension, usually gender or type of director. A large number of papers have found a positive relationship between gender diversity and firm performance (Campbell \& Mínguez-Vera, 2008; E-Vahdati, Zulkifli, \& Zakaria, 2018; Galbreath, 2018; Green \& Homroy, 2018; Martín-Ugedo, Mínguez-Vera, \& Palma-Martos, 2018), while others have found a negative relationship (Adams \& Ferreira, 2009) or even

\footnotetext{
*E-mail: alvaro.melon@unirioja.es.

Citation: Melón-Izco, Á., Ruiz-Cabestre, F. J., and Ruiz Olalla, M. C. (2020) Diversity in the board of directors and good governance practices, Economics and Business Letters, 9(2), 97-105.
}

DOI: 10.17811/ebl.9.2.2020.97-105 
no relationship (Carter, D'Souza, Simkins, \& Simpson, 2010). Regarding types of director, numerous papers have studied the relationship between independence or outside directors and firm performance with mixed results. For example, Lefort and Urzúa (2008) found a positive relationship between outside directors and firm value, while Cavaco et al. (2016) identified a negative one.

However, boards of directors should engage in balancing stakeholder interests (Al-Shaer \& Zaman, 2016), which involves not focusing purely on financial concerns. For this, interest is focused on analyzing whether the degree of diversity of the board leads to a significant impact on the governance functions (Fitzsimmons, 2012; Gul, Hutchinson, \& Lai, 2013; Singh \& Vinnicombe, 2004; Srinidhi, Gul, \& Tsui, 2011). Studies on this issue are not as neat as those related to financial performance. Bear et al. (2010), Hafsi and Turgut (2013) and Harjoto et al. (2015), among others, provide evidence of a link between gender diversity and corporate social responsibility. Other studies analyse gender diversity and sustainability reporting quality (AlShaer \& Zaman, 2016; Cabeza-García, Fernández-Gago, \& Nieto, 2018), or female board participation and annual report readability (Ginesti, Drago, Macchioni, \& Sannino, 2018), or the relationship between the composition of board of directors and the disclosure of voluntary disclosure (Cucari, 2019; Lagasio \& Cucari, 2019; Lim, Matolcsy, \& Chow, 2007). However, there is no empirical evidence on the relationship between board diversity and corporate governance performance. Despite this, literature suggests that a more heterogeneous board composition develops government processes that are more open to stakeholder demands (Hillman, Cannella, \& Harris, 2002), that consequently allow the alignment of all interests (Tirole, 2001). In this context it is essential to assess whether the board of directors follows good governance practices (Rose, 2016).

In this regard, this paper aims to answer the following research question: What is the relationship, if any, between board diversity and corporate governance performance? Thus, we examine the effect of board diversity in a broad sense on good governance practices for the Spanish context. We study this research question through three different hypotheses:

H1: Gender diversity has a positive effect on corporate governance performance.

H2: Diversity of types of directors has a positive effect on corporate governance performance.

H3: Tenure diversity has a positive effect on corporate governance performance.

This work makes several contributions. First, it adds to the scarce empirical evidence on good governance practices. Second, it analyses the diversity of directors in the boardroom in a broad sense through three dimensions (gender, typology, and tenure). Third, the US, where most previous evidence comes from, is considered a common law country. In contrast, Spain is a civil law country. Countries under common law systems tend to have more dispersed ownership structures, stronger investor protection and more effective external control mechanisms, differences that affect corporate governance. Fourth, it corrects the main methodological limitations that, according to Cuomo et al. (2016), are present in previous studies, such as the lack of control for specific firm characteristics, the use of Ordinary Least Squares (OLS) regressions, the problem of unobserved heterogeneity among companies, and the lack of control for endogeneity and selection bias. This paper can contribute to the debate on the regulatory requirements regarding the composition of boards of directors being of interest to regulators. It could also be of interest to practitioners, since it provides empirical evidence that diversity improves good governance practices.

The paper is organised as follows. The next section describes the methodology. Section 3 contains estimation results and discussion, whilst Section 4 provides some concluding remarks. 


\section{Methodology}

\subsection{Data}

The sample is comprised of Spanish companies listed on the Continuous Market of the Madrid Stock Exchange, excluding those companies that belong to the financial or real estate sectors. This exclusion is due to the existence of specific good governance codes for these companies. The time period of the research covers 2010 to 2014, since in 2015 a new Good Governance Code (CNMV, 2015) was implemented; this is not comparable with the previous ones and limits the period of study. As a result, our final sample consists of 430 firm-year observations.

To build our database, we obtained the data through the Annual Corporate Governance Reports of these companies, particularly the section related to the structure of the board of directors and the section that refers to the degree of compliance with the recommendations proposed by the codes of good governance. We also obtained financial data through the SABI database.

\subsection{Variables}

Our dependent variable is good governance practices as a measurement of corporate governance performance. We used the degree of compliance with the recommendations of good governance following previous literature (Alves \& Mendes, 2004; Price, Román, \& Rountree, 2011). When companies face a recommendation, they can choose to fully comply with it, partially comply with it, not comply with it or not apply it. In order to measure the degree of compliance with these recommendations, we have taken into account both total and partial compliance in a weighted way and this has been linked to the number of recommendations with which a company can comply. We have thus created the Good Governance Practices (GGP) variable as follows ${ }^{1}$ :

GGP

$=\frac{\text { recommendations totally complied with } \cdot 1+\text { recommendations partially complied with } \cdot 0.5}{\text { total recommendations }- \text { recommendations not applicable }}$

The aim of our research is to explain this variable through the diversity of the board of directors. For this, we have considered three independent variables to measure different types of diversities within the boardroom: gender diversity (Gender), diversity of director types (Typology), and tenure diversity (Tenure). The first two variables were measured through the Blau index, which is frequently used in empirical research on organisational demography to represent group heterogeneity. It is formulated as in equation [2], where $p_{i}$ is the proportion of each category analysed (gender diversity is composed of two categories: men and women; and typology diversity is composed of three categories: executive, proprietary, and independent director). Tenure diversity is measured as the coefficient of variation of the tenure of the board of directors in each observation.

$$
\text { Blau index }=1-\sum_{i=1}^{n} p_{i}^{2}
$$

We used two types of control variables: corporate governance variables and firm characteristics. The former have been chosen according to the majority of literature on corporate governance and following the paper of Lagasio and Cucari (2019), where it makes a meta-analysis of evidence about the influence of the corporate governance on disclosure. These variables have been board size, computed as the logarithm of the number of board members (B_Size); board remuneration, measured as the logarithm of total board remuneration (B_Remmuneration); au-

\footnotetext{
${ }^{1}$ Of all the recommendations, there are two that have to do with the gender and the independent directors. To avoid endogeneity issues, we have removed, both in the numbered and in the denominator, these recommendations.
} 
dit committee meetings, quantified as the logarithm of the number of meetings in that committee (AC_Meetings); and CEO duality, which is a binary variable equal to one if the chairperson and CEO were the same and zero otherwise (CEO_duality). The latter are firm size, quantified as the logarithm of total assets (F_Size); ownership dispersion, measured as the percentage of shares held by the public (Ownership); book-to-market ratio, calculated as the quotient between book value and the market value of equity (Book-to-market); firm age, quantified as the logarithm of firm age (F_Age); and level of indebtedness, measured as the quotient between total debt and total assets (F_Leverage). Finally, year dummies and industry dummies were included to control for temporal and industry effects.

\subsection{Empirical model}

To capture the effect of boardroom diversity on good governance practices, we propose a panel data model with a dependent variable censored by the upper limit because a large proportion of the values is concentrated in the highest value (that is, in the unit). The regression model is specified as:

$$
\mathrm{GGP}_{\mathrm{it}}=\beta_{0}+\beta_{1} \cdot \text { Gender }_{\mathrm{it}}+\beta_{2} \cdot \text { Typology }_{\mathrm{it}}+\beta_{3} \cdot \text { Tenure }_{\mathrm{it}}+\Sigma \beta_{\mathrm{j}} \cdot \text { Controlj }_{\mathrm{it}}+\varepsilon_{\mathrm{it}}
$$

where subscript i and subscript t refer to firm and time, respectively; GGP represents good governance practices; Gender is gender diversity; Typology refers to the diversity of director types; Tenure captures tenure diversity; and Controlj is the corresponding control variable $\mathrm{j}$, which has been previously described. Finally, $\varepsilon_{\text {it }}$ is the error term, which is split into three components: the individual effect $\left(\eta_{i}\right)$, the temporal effect $\left(d_{t}\right)$, and white noise or random disturbance $\left(v_{\text {it }}\right)$.

These models with censored dependent variables were estimated through random effects using a likelihood function. Random effects estimators were used because there are no fixed effects estimators that are efficient in models with censored variables. The panel data methodology was used to avoid obtaining biased estimates due to the problem of unobservable heterogeneity.

To provide robustness, we incorporated three additional regression models to the main one. Thus, model (2) was run only with the variables that were statistically significant in model (1). Model (3) was added to examine a possible critical mass effect in gender diversity. Finally, model (4) incorporates lagged-one-year independent variables in order to mitigate endogeneity concerns.

\section{Results and discussion}

Table 1 shows the descriptive statistics of all the variables used. A few statistics are noteworthy. The average compliance with good governance practices is $89.66 \%$, with a standard deviation of $8.29 \%$, and half of companies meet more than $91 \%$ of the recommendations. This trend has gained traction in recent years, as the literature suggests. Board composition is not balanced in terms of gender, since the mean of diversity index is 0.1743 (the Blau index goes from zero to 0.5 , representing 0.5 equality between men and women). In fact, the average percentage of women on the boards of directors is only $10.96 \%$. Regarding the diversity of director types, the average reaches a value of 0.5212 (the Blau index goes from zero to 0.6667 , representing 0.6667 equality between executive, proprietary, and independent directors), and the standard deviation is 0.1317 . Regarding tenure in the board, the directors remain in the company for an average of 8 years. This variable presents an average of 0.7370 with a standard deviation of 0.2713 .

We examine whether the different types of diversities in the board have a positive influence on corporate governance performance, measured through good governance practices. To this end, Table 2 shows the results of the regression performed for the aforementioned empirical model. The whole model is displayed in Column (1), while a reduced model with only significant variables is shown in Column (2) to provide robustness to the results. 
Table 1. Descriptive statistics.

\begin{tabular}{|c|c|c|c|c|c|c|c|c|}
\hline Variable & Mean & Std. dev. & Min & $1^{s t} Q$ & Median & $3^{e r} Q$ & $\operatorname{Max}$ & $N$ \\
\hline$G G P$ & 0.8966 & 0.0829 & 0.5833 & 0.8571 & 0.9130 & 0.9583 & 1.0000 & 430 \\
\hline Gender & 0.1743 & 0.1437 & 0.0000 & 0.0000 & 0.1738 & 0.2808 & 0.4938 & 430 \\
\hline Typology & 0.5212 & 0.1317 & 0.0000 & 0.4686 & 0.5518 & 0.6172 & 0.6667 & 430 \\
\hline Tenure & 0.7370 & 0.2713 & 0.0000 & 0.5641 & 0.7149 & 0.8622 & 2.1887 & 430 \\
\hline B_Size & 10.6349 & 3.5563 & 3.0000 & 8.0000 & 10.0000 & 13.0000 & 21.0000 & 430 \\
\hline B_Remmuneration & 265.2730 & 307.2800 & 0.0000 & 84.2071 & 162.3177 & 326.4615 & $2,808.0730$ & 430 \\
\hline AC_Meetings & 6.1535 & 2.4072 & 0.0000 & 5.0000 & 6.0000 & 7.0000 & 17.0000 & 430 \\
\hline F_Size & $8,146,546$ & $19,972,480$ & 3,166 & 240,706 & 964,929 & $3,864,871$ & $129,775,000$ & 430 \\
\hline Ownership & 0.4333 & 0.2162 & 0.0085 & 0.2760 & 0.3841 & 0.5811 & 0.9996 & 430 \\
\hline Book-to-market & 1.0831 & 1.5360 & -7.1639 & 0.4118 & 0.7817 & 1.4583 & 12.9107 & 430 \\
\hline$F \_A g e$ & 54.9698 & 44.4485 & 0.0000 & 24.0000 & 44.0000 & 71.0000 & 289.0000 & 430 \\
\hline \multirow[t]{3}{*}{$F \_$Leverage } & 0.6710 & 0.5945 & 0.0403 & 0.5002 & 0.6529 & 0.7669 & 11.4094 & 430 \\
\hline & & Frequency & & & Percentage & & & \\
\hline & No & Yes & Total & No & Yes & Total & & \\
\hline CEO_Duality & 241 & 189 & 430 & 56.05 & 43.95 & 100.00 & & \\
\hline
\end{tabular}

When reviewing the model as a whole, there is a positive and statistically significant relationship between gender diversity on the board and good governance practices, so in terms of gender the more balanced the board of directors is, the more the board complies with the recommendations of good governance practices. Thus, gender diversity does not only have a positive influence over financial performance (Campbell \& Mínguez-Vera, 2008; E-Vahdati et al., 2018; Galbreath, 2018; Green \& Homroy, 2018; Martín-Ugedo et al., 2018), but also corporate governance performance, so hypothesis $\mathrm{H} 1$ is verified. These results are in line with the paper of Cucari et al. (2018), which also found a positive relationship with respect to governance disclosure. We can also observe that the variety of director types in companies has a positive and statistically significant influence on the dependent variable. In this sense, large proportion of independent directors is not only important to improve corporate performance (Leffort \& Urzúa, 2008), but also a diversity of each one of them. This leads us to verify hypothesis H2. Finally, tenure diversity is statistically significant and positively affects the proportion of recommendations with which a company has complied. This shows that a board of directors with a variety of tenures improves good governance performance, fulfilling the hypothesis $\mathrm{H} 3$. Therefore, we demonstrate that a more balanced board is also a more talented board, where directors can improve corporate governance performance and bring in different professional experiences, skills, and diverse perspectives (Bear et al., 2010; Nielsen \& Huse, 2010). Thereby, we can highlight that diversity in the board of directors does not only improve the different types of performance in common law countries such as the United States or UK, but also in civil law countries, as it is in Spain and most European countries.

Regarding the control variables, board size appears to be a statistically significant variable with a positive sign. Thus, larger boards of directors have more resources that allow them to comply with more recommendations. In addition, there is a positive and statistically significant relationship between the number of meetings in the audit committee and good governance practices. Audit committees are in charge of monitoring compliance with the rules of corporate governance, so it is likely that the greater the number of meetings, the better it will carry out this function, resulting in a greater degree of compliance with the recommendations. There is a positive and statistically significant relationship between the size of the company and good governance practices. It is well known that large companies are also more visible and their information is more exposed with respect to their stakeholders, so they will be more concerned about good governance practices. According to agency theory, ownership dispersion is also positive and statistically significant. If a company's ownership structure is very dispersed, 
agency costs rise due to the increase in the likelihood of conflicts of interest between owners and managers (Jensen \& Meckling, 1976). In order to reduce these costs, the companies will carry out the best possible corporate governance practices. Finally, the age of the company negatively affects compliance with the recommendations, probably because young companies are more aware of good governance practices.

To check the validity of the results, we ran a reduced regression model (2) with only the significant variables. The results are fairly similar to those of the previous model, since all the variables remain statistically significant and there are no sign variations. Wald tests allow us to test the joint significance of the explanatory variables of the models, and likelihood tests agree that these panel data models with censored variables are preferable to pooled models. The Rho coefficients reveal that $80.58 \%$ and $80.08 \%$ of the variance, respectively, is due to the panel data structure. Variance Inflation Factors (VIF) were computed for both regressions in order to confirm that there were no problems with multicollinearity.

Table 2. Influence of diversity on good governance practices.

\begin{tabular}{|c|c|c|c|c|}
\hline \multirow{4}{*}{ Independent variables } & \multicolumn{4}{|c|}{ Dependent variables } \\
\hline & (1) & (2) & (3) & (4) \\
\hline & GGP & GGP & GGP & GGP \\
\hline & $\begin{array}{r}\text { Coefficient } \\
\text { (p-value) }\end{array}$ & $\begin{array}{r}\text { Coefficient } \\
\text { (p-value) }\end{array}$ & $\begin{array}{r}\text { Coefficient } \\
\text { (p-value) }\end{array}$ & $\begin{array}{r}\text { Coefficient } \\
\text { (p-value) }\end{array}$ \\
\hline Constant & $\begin{array}{r}0.7353 * * * * \\
(0.000)\end{array}$ & $\begin{array}{r}0.7362 * * * \\
(0.000)\end{array}$ & $\begin{array}{r}0.5999 * * * * \\
(0.000)\end{array}$ & $\begin{array}{r}0.7468 * * * \\
(0.000)\end{array}$ \\
\hline Gender & $\begin{array}{r}0.0780 * * * \\
(0.000)\end{array}$ & $\begin{array}{r}0.0783 * * * * \\
(0.000)\end{array}$ & $\begin{array}{c}0.0062 \\
(0.316)\end{array}$ & $\begin{array}{r}0.0589 * * * \\
(0.000)\end{array}$ \\
\hline Typology & $\begin{array}{r}0.0622 * * * * \\
(0.000)\end{array}$ & $\begin{array}{r}0.0653 * * * * \\
(0.000)\end{array}$ & $\begin{array}{r}0.0717 * * * * \\
(0.000)\end{array}$ & $\begin{array}{r}0.0678 * * * \\
(0.000)\end{array}$ \\
\hline Tenure & $\begin{array}{r}0.0199 * * \\
(0.011)\end{array}$ & $\begin{array}{r}0.0162 * * \\
(0.048)\end{array}$ & $\begin{array}{l}0.0295 \\
(0.128)\end{array}$ & $\begin{array}{r}0.0210^{* * * *} \\
(0.008)\end{array}$ \\
\hline \multicolumn{5}{|l|}{ Control variables } \\
\hline B_Size & $\begin{array}{r}0.0161^{* *} \\
(0.019)\end{array}$ & $\begin{array}{r}0.0169 * * \\
(0.016)\end{array}$ & $\begin{array}{l}0.0015 \\
(0.899)\end{array}$ & $\begin{array}{r}0.0132 * \\
(0.085)\end{array}$ \\
\hline B_Remmuneration & $\begin{array}{r}-0.0011 \\
(0.629)\end{array}$ & & & \\
\hline AC_Meetings & $\begin{array}{r}0.0101 * * \\
(0.032)\end{array}$ & $\begin{array}{r}0.0111 * * \\
(0.017)\end{array}$ & $\begin{array}{r}0.0141 * * * \\
(0.002)\end{array}$ & $\begin{array}{l}0.0067 \\
(0.136)\end{array}$ \\
\hline CEO_duality & $\begin{array}{r}-0.0036 \\
(0.423)\end{array}$ & & & \\
\hline F_Size & $\begin{array}{r}0.0099 * * * \\
(0.000)\end{array}$ & $\begin{array}{r}0.0090^{* * * *} \\
(0.000)\end{array}$ & $\begin{array}{r}0.0129 * * * \\
(0.000)\end{array}$ & $\begin{array}{r}0.0103^{* * *} \\
(0.000)\end{array}$ \\
\hline Ownership & $\begin{array}{r}0.0289 * * * \\
(0.002)\end{array}$ & $\begin{array}{r}0.0286 * * * * \\
(0.003)\end{array}$ & $\begin{array}{r}0.0774 * * * \\
(0.052)\end{array}$ & $\begin{array}{r}0.0244 * * \\
(0.021)\end{array}$ \\
\hline Book-to-market & $\begin{array}{r}0.0007 \\
(0.685)\end{array}$ & & & \\
\hline$F_{-}$Age & $\begin{array}{r}-0.0213^{* * *} \\
(0.000)\end{array}$ & $\begin{array}{r}-0.0205^{* * *} \\
(0.000)\end{array}$ & $\begin{array}{r}-0.0067 * \\
(0.079)\end{array}$ & $\begin{array}{r}-0.0226^{* * * *} \\
(0.000)\end{array}$ \\
\hline F_Leverage & $\begin{array}{r}0.0031 \\
(0.305)\end{array}$ & & & \\
\hline Year dummies & Yes & Yes & Yes & Yes \\
\hline Industry dummies & Yes & Yes & Yes & Yes \\
\hline Observations/Groups & $430 / 87$ & $430 / 87$ & $430 / 87$ & $343 / 87$ \\
\hline Wald test & $\begin{array}{r}612.80 * * * \\
(0.000)\end{array}$ & $\begin{array}{r}582.93 * * * \\
(0.000)\end{array}$ & $\begin{array}{r}618.91 * * * \\
(0.000)\end{array}$ & $\begin{array}{r}565.40 * * * \\
(0.000)\end{array}$ \\
\hline Likelihood test & $\begin{array}{r}392.37 * * * \\
(0.000)\end{array}$ & $\begin{array}{r}399.19 * * * \\
(0.000)\end{array}$ & $\begin{array}{r}393.82 * * * * \\
(0.000)\end{array}$ & $\begin{array}{r}339.58 * * * \\
(0.000)\end{array}$ \\
\hline$V I F$ & $1.08-3.77$ & $1.02-2.00$ & $1.02-2.10$ & $1.01-2.01$ \\
\hline Rho $(\rho)$ & 0.8058 & 0.8008 & 0.7906 & 0.8361 \\
\hline
\end{tabular}

Notes: * Significant at $10 \%$. ** Significant at $5 \%$. *** Significant at $1 \%$. 


\subsection{Robustness check}

Critical mass theory (Granovetter, American, May, \& Granovetter, 2007; Kanter, 1987) was also used in the analysis to examine a specific aspect of the research question: the expected consequences on good governance practices of having female directors may depend not only on their diversity but also on reaching an appropriate threshold number. Critical mass theory (Granovetter et al., 2007; Kanter, 1987) suggests that the nature of group interactions depends upon size. When the size of the subgroup reaches a certain threshold, or critical mass, the subgroup's degree of influence increases. In the board of directors' context, if only one seat is held by a woman, she will probably be considered a token and less competent, making her status lower than the men's (Bear et al., 2010). Thus, she will not have a significant impact on corporate decision making (Jia \& Zhang, 2013). Therefore, critical mass theory incorporates an additional aspect to be considered for a full explanation of the impact of gender diversity on corporate issues (Torchia, Calabrò, \& Huse, 2011). Three has been regarded as an appropriate threshold number and has been used as the minimum number of women required to exert significant power and cause fundamental changes in the boardroom (Jia \& Zhang, 2013).

In this way, we ran again the regression model (2) including a new variable, women3, which replaces the gender diversity variable. This is a binary variable that takes the value of one if three or more women were sited on the boardroom, and zero otherwise. The results in this model (3) are quite similar to those obtained in models (1) and (2) for the rest of variables. However, no critical mass effect was found in our model, since women 3 variable was not statistically significant. This may be due to the fact that the average number of women on the boards of directors during the period analyzed is only 1.19 women. For this reason, it doesn't make much sense to demand a minimum of three female directors. A critical mass of three seemed to be more appropriate for the other countries (i.e. United States), where the figure of female director is more common in companies.

Himmelberg (2002) argued that corporate governance is determined exogenously by environmental factors such as legal efficiency, regulation and the rules relating to the market for corporate control. In our study, the environmental factor is the good governance practices. As Coles et al. (2008) argue, firm-level governance must therefore be treated as endogenous. There is a significant literature recognizing that models containing corporate governance variables suffer from endogeneity (Hermalin \& Weisbach, 1991; Beiner, Drobetz, Schmid, \& Zimmermann, 2004). The particular form of endogeneity faced in governance is simultaneity whereby agency costs and the right-hand side variables may be simultaneously determined.

To double-check robustness of the results, model (2) was re-estimated in model (4) to mitigate endogeneity concerns. We adopt the approach used by Hermalin and Weisbach (1991) and use the lagged values of the endogenous variables as instruments. We can confirm the findings obtained for models (1) and (2), since the results in model (4) are very similar to those ones. That is, gender diversity, typology of directors' diversity and tenure diversity is positively related to the compliance of good governance practices, even dealing with endogeneity problems.

\section{Concluding remarks}

Several organisations and countries have developed laws and recommendations regarding corporate governance in order to improve the effective application and monitoring of corporate governance mechanisms. Motivated by these changes, which are a consequence of the last financial crisis, this study examines the importance of boardroom diversity. The results highlight the importance of diversity contexts in corporate governance performance.

The results obtained in this paper suggest that the more diverse the board of directors is, the better the corporate governance practices of the companies are. When we study diversity, we pay attention to gender diversity (between men and women), the diversity of director types (executives, proprietary, and independent directors), and the diversity of tenures in the board. 
These results may have implications for practitioners, since it is shown that different types of diversity contribute to better corporate governance. They may also be of interest to regulators, who are rightly promoting laws and regulations aimed at achieving diversity in the knowledge, experiences, and gender of the board of directors.

As limitations of this research, we point out that the period analysed ends in 2014. Future research could be extended analysing a more updated period, taking into account the good governance practices of the new Unified Code of Good Governance as of 2015. Since Spain is a civil law country, it would also be interesting to conduct a comparative study between civil law countries and common law countries, as a new future research line.

\section{Acknowledgments}

This work was supported by the Ministry of Economy and Competitiveness of Spain (ECO201677631-R) and the University of La Rioja (REGI2018/24).

\section{References}

Adams, R. B., and Ferreira, D. (2009) Women in the boardroom and their impact on governance and performance, Journal of Financial Economics, 94(2), 291-309.

Al-Shaer, H., and Zaman, M. (2016) Board gender diversity and sustainability reporting quality, Journal of Contemporary Accounting and Economics, 12(3), 210-222.

Alves, C., and Mendes, V. (2004) Corporate governance policy and company performance: The Portuguese case, Corporate Governance: An International Review, 12(3), 290-301.

Bear, S., Rahman, N., and Post, C. (2010) The Impact of Board Diversity and Gender Composition on Corporate Social Responsibility and Firm Reputation, Journal of Business Ethics, 97(2), 207221.

Beiner, S., Drobetz, D. W., Schmid, F., and Zimmermann, H. (2004) Is board size an independent corporate governance mechanism?, Kyklos, 57(3), 327-356.

Cabeza-García, L., Fernández-Gago, R., and Nieto, M. (2018) Do Board Gender Diversity and Director Typology Impact CSR Reporting?, European Management Review, 15(4), 559-575.

Campbell, K., and Mínguez-Vera, A. (2008) Gender Diversity in the Boardroom and Firm Financial Performance, Journal of Business Ethhics, 83(1), 435-451.

Carter, D. A., D'Souza, F., Simkins, B. J., and Simpson, W. G. (2010) The gender and ethnic diversity of US boards and board committees and firm financial performance, Corporate Governance: An International Review, 18(5), 396-414.

Cavaco, S., Challe, E., Crifo, P., Rebérioux, A., and Roudaut, G. (2016) Board independence and operating performance: analysis on (French) company and individual data, Applied Economics, 48(52), 5093-5105.

CNMV (2015) Código de buen gobierno de las sociedades cotizadas.

Coles, J. L., Daniel, N. D., and Naveen, L. (2008) Boards: Does one size fit all?, Journal of Financial Economics, 87(2), 329-356.

Cucari, N. (2019) Qualitative comparative analysis in corporate governance research: a systematic literature review of applications, Corporate Governance, 19(4), 717-734.

Cucari, N., Esposito De Falco, S., and Orlando, B. (2018) Diversity of Board of Directors and Environmental Social Governance: Evidence from Italian Listed Companies, Corporate Social Responsibility and Environmental Management, 25(3), 250-266.

Cuomo, F., Mallin, C., and Zattoni, A. (2016) Corporate Governance Codes: A Review and Research Agenda, Corporate Governance: An International Review, 24(3), 222-241.

E-Vahdati, S., Zulkifli, N., and Zakaria, Z. (2018) A moderated mediation model for board diversity and corporate performance in ASEAN countries, Sustainability, 10(2).

Fitzsimmons, S. R. (2012) Women on boards of directors: Why skirts in seats aren't enough, Business Horizons, 55(6), 557-566. 
Galbreath, J. (2018) Is Board Gender Diversity Linked to Financial Performance? The Mediating Mechanism of CSR, Business and Society, 57(5), 863-889.

Ginesti, G., Drago, C., Macchioni, R., and Sannino, G. (2018) Female board participation and annual report readability in firms with boardroom connections, Gender in Management, 33(4), 296-314.

Granovetter, M., American, T., May, N., and Granovetter, M. (2007) Threshold Models of Collective Behavior Threshold Models of Collective Behavior, 83(6), 1420-1443.

Green, C. P., and Homroy, S. (2018) Female directors, board committees and firm performance, European Economic Review, 102, 19-38.

Gul, F. A., Hutchinson, M., and Lai, K. M. Y. (2013) Gender-Diverse Boards and Properties of Analyst Earnings Forecasts, Accounting Horizons, 27(3), 511-538.

Hafsi, T., and Turgut, G. (2013) Boardroom Diversity and its Effect on Social Performance: Conceptualization and Empirical Evidence, Journal of Business Ethics, 112(3), 463-479.

Harjoto, M., Laksmana, I., and Lee, R. (2015) Board Diversity and Corporate Social Responsibility, Journal of Business Ethics, 132(4), 641-660.

Hermalin, B., and Weisbach, M. (1991) The Effects of Board Composition and Direct Incentives on Firm Performance, Financial Management, 20(4).

Hillman, A. J., Cannella, A. A., and Harris, I. C. (2002) Women and Racial Minorities in the Boardroom: How Do Directors Differ?, Journal of Management, 28(6), 747-763.

Himmelberg, C. P. (2002) Measuring the real effects of corporate governance in: A Note for the GCGF Research Meeting, Washington DC, US.

Jensen, M. C., and Meckling, W. H. (1976) Theory of the firm: Managerial behavior, agency costs and ownership structure, Journal of Financial Economics, 3(4), 305-360.

Jia, M., and Zhang, Z. (2013) Critical Mass of Women on BODs, Multiple Identities, and Corporate Philanthropic Disaster Response: Evidence from Privately Owned Chinese Firms, Journal of Business Ethics, 118(2), 303-317.

Kanter, R. M. (1987) Men and Women of the Corporation Revisited, Management Review, 76(3), $14-16$.

Lagasio, V., and Cucari, N. (2019) Corporate governance and environmental social governance disclosure: A meta-analytical review, Corporate Social Responsibility and Environmental Management, 26(4), 701-711.

Lefort, F., and Urzúa, F. (2008) Board independence, firm performance and ownership concentration: Evidence from Chile, Journal of Business Research, 61(6), 615-622.

Lim, S., Matolcsy, Z., and Chow, D. (2007) The association between board composition and different types of voluntary disclosure, European Accounting Review, 16(3), 555-583.

Martín-Ugedo, J. F., Mínguez-Vera, A., and Palma-Martos, L. (2018) Female CEOs, Returns and Risk in Spanish Publishing Firms, European Management Review, 15(1), 111-120.

Nielsen, S., and Huse, M. (2010) The contribution of women on boards of directors: Going beyond the surface, Corporate Governance: An International Review.

Price, R., Román, F. J., and Rountree, B. (2011) The impact of governance reform on performance and transparency, Journal of Financial Economics, 99(1), 76-96.

Rose, C. (2016) Firm performance and comply or explain disclosure in corporate governance, European Management Journal, 34(3), 202-222.

Singh, V., and Vinnicombe, S. (2004) Why So Few Women Directors in Top UK Boardrooms? Evidence and Theoretical Explanations, Corporate Governance: An International Review, 12(4), 479-488.

Srinidhi, B., Gul, F. A., and Tsui, J. (2011) Female directors and earnings quality, Contemporary Accounting Research, 28(5), 1610-1644.

Tirole, J. (2001) Corporate Governance. Econometrica, 69(1), 1-35.

Torchia, M., Calabrò, A., and Huse, M. (2011) Women Directors on Corporate Boards: From Tokenism to Critical Mass, Journal of Business Ethics, 102(2), 299-317. 